\title{
Earth Sciences and History in the Work of Correia da Serra (1751-1823)
}

\section{Ciências da Terra e História na obra de Correia da Serra (1751-1823)}

\author{
ANA SIMÕES \\ Centro Interuniversitário de História das Ciências e Tecnologia \\ Faculdade de Ciências \\ Universidade de Lisboa \\ 1749-016 Lisboa, Portugal \\ aisimoes@fc.ul.pt \\ ANA CARNEIRO \\ Centro Interuniversitário de História das Ciências e Tecnologia \\ Faculdade de Ciências e Tecnologia \\ Universidade NOVA de Lisboa \\ Campus de Caparica, Portugal \\ amoc@fct.unl.pt \\ Maria Paula DiOgO \\ Centro Interuniversitário de História das Ciências e Tecnologia \\ Faculdade de Ciências e Tecnologia \\ Universidade NOVA de Lisboa, \\ Campus de Caparica, Portugal \\ mpd@fct.unl.pt
}

Received: 17 Apr. 2017 | Reviewed by the authors: 30 Jun. 2017 | Accepted: 3 Jul. 2017

http://dx.doi.org/10.1590/0104-87752017000300005

Varia Historia, Belo Horizonte, vol. 33, n. 63, p. 625-656, set/dez 2017 
Abstract This paper focuses on the contribution to the earth sciences of the Portuguese botanist and "Europeanized intellectual" Abbé José Francisco Correia da Serra (1751-1823). Considerations on the earth sciences are present since the very early days of Correia da Serra's career, revealing an integrated vision of Man and Nature as dynamical parts of the same whole, which shapes the world inhabited by humans. The symbiosis between the natural and the human became central to the epistemological and methodological agenda of Correia da Serra, informing his historical considerations, first on the history of Portugal, followed by the history of Europe. In this paper, we explore how the parallel reflections on the earth sciences and history unfold by testing the operative import of the concept of "moving localities" in interpreting them jointly as ways of historicizing nature and naturalizing history. KEYWORDS earth sciences, historicizing nature, naturalizing history

RESumo Este artigo debruça-se sobre as contribuições na área das ciências da terra do estrangeirado e botânico português José Francisco Correia da Serra (1751-1823). O interesse pelas ciências da terra está presente desde cedo na obra de Correia da Serra, integrando a sua visão do Homem e da Natureza como partes dinâmicas de um mesmo todo que molda o mundo que nos cerca e em que vivemos. Esta simbiose entre o natural e o humano marca a postura metodológica e epistemológica do Abade, constituindo a matriz interpretativa do seu programa de investigação, que começou pela História de Portugal e a que se seguiram reflexões sobre a história da Europa. Neste artigo, avaliamos o desenrolar das reflexões sobre ciências da terra e história e mostramos como o conceito de "moving localities" permite interpretá-las conjuntamente como modos de historicizar a natureza e de naturalizar a história.

Palavras-chave ciências da terra, historicização da natureza, naturalização da história 


\section{INTRODUCTION}

The Portuguese naturalist Abbé Correia da Serra (1751-1823) was one among many Portuguese "Europeanized" intellectuals - estrangeirados -, who travelled far and wide often to evade political or religious persecutions (Macedo, 1979; Palma-Ferreira, 1987; Miranda, 1990; Simões; Carneiro; Diogo, 1999; Carneiro; Simões; Diogo, 2000). A polymath, founder of the Academy of Sciences of Lisbon, diplomat and first Portuguese ambassador in the United States of America, he succeeded in carving a place among the European scientific elite of his time as an acute and knowledgeable botanist.

In former papers and books, we explored various facets of Correia da Serra's contributions to science by integrating them in the exchanges nurtured by his constant travelling experiences. We have argued ever since that they enabled him to become an active player in extended networks of scientists and intellectuals, including Joseph Banks (1743-1820), James Edward Smith (1759-1828), Augustin Pyramus de Candolle (1778-1841), Georges Cuvier (1769-1832), Alexander von Humboldt (1769-1859), and Thomas Jefferson (1743-1826) with whom he botanized and discussed various topics, which fostered his original proposals on various aspects of botany (Diogo; Carneiro; Simões, 2001; Carneiro; Simões; Diogo, 2003; Simões; Carneiro; Diogo, 2003; Simões; Diogo; Carneiro, 2006; 2012).

Building on our knowledge of Correia da Serra's scientific contributions and impact, in this paper we argue that one cannot write a nuanced and complex history of the sciences in Europe in its relation to the world on the basis of a small group of great luminaries or grand narratives of individual successes. It is by changing the focus of analysis to clusters of scientists absent from mainstream standard narratives that a richer picture emerges. This idea is closely tied with notions about circulation as a knowledge-making process developed by scholars such as James Secord, Kapil Raj, Lissa Roberts, Sujit Sivasundaram and Arjun Appadurai to name a few, to give visibility to non-European contexts (Raj, 2007; 2010; 2013; Appadurai, 2001; Secord, 2004; Roberts, 2009; 
Sivasundaram, 2010), but opposes staunchly, as Xavier Polanco's idea of world-science already suggested in the 1990s (Polanco, 1990), the flattening of asymmetries that they often advocate, and re-centers historical accounts on Europe while dismissing Eurocentrism. In fact, in the meantime the vantage point of the European Periphery, as voiced by the international group Science and Technology in the European Periphery (STEP) (Gavroglu et al., 2008; Gavroglu, 2012) has drawn attention to the need of seriously taking into consideration the exchanges, mediations and negotiations taking place mostly within Europe, as integral components of global accounts (Patiniotis, 2013; Raposo et al., 2014; Diogo; Gavroglu; Simões, 2016), and has argued for the co-construction of centers and peripheries, insisting on a serious assessment of how asymmetries, including power asymmetries, are built and evolve. It has re-asserted the creative role of European "invisible" actors, intermediaries and go-betweens, "backward" institutional settings, regions and countries, calling for a revision of standard historiographical accounts, and showing that "invisibility" and "backwardness" have to be understood historically. In the case of Correia da Serra, one needs to grasp how despite his high reputation among contemporary experts, a few decades after his death he had already been forgotten. ${ }^{1}$ It is our contention that an analysis centered on the interactions of clusters of scientists enables one to do so, when integrated in the STEP framework and when taking also into consideration the interference of various other clusters - political, ideological, religious, and so on - in the scientific realm. Additionally, among other outcomes, STEP's recent reassessments have given rise to the proposal of "moving localities" as a new historiographical concept meant to deepen the creative strength of circulation as a continuous process of knowledge production, which should not

1 Abbreviations used: ANTT - Arquivos Nacionais da Torre do Tombo. CANDOLLE, Augustin Pyramus. Mémoires et Souvenirs de Agustin-Pyramus de Candolle écrits par lui-même et publiés par son fils. Geneva, 1862, p.163. When Augustin Pyramys de Candolle's son, Alphonse, edited his father recollections, he found it hard to accept that an obscure southern-European wanderer could have had such a degree of influence on his father's botanical accomplishments, and suggested that his alleged ideas were more likely to be due to the Scottish botanist Robert Brown. 
be restricted to discontinuities associated with encounters in certain places (Raposo et al., 2014). Behind the notion of moving localities is the realization that one should disentangle the notion of locality from the physical notion of location, and the belief that to be operative locality should mean a complex set of connections, allegiances and commitments which travel with people, and thus extend beyond perceived and effectively marked boundaries, creating interconnected intellectual spaces over wide geographical locations. In a nutshell, in each point of his/her trajectory the traveller is the siege of influences, stemming from the various locations s/he passed through, and most forcefully from those of his/her place of origin, which give rise to a dynamical stratigraphy of values, which is continually updated with new interactions. This new sense of locality enables historians to recognize that actors perform distinct cultural identities in the course of their travels, informed, but not confined by those assigned by their places of origin. That is, locality can be said to be a local culture made active and open to transformations thanks to encounters fostered by travel conditions.

In this paper, we use the lens provided by STEP's insistence on the existence of shifting centers and peripheries, denoting an effective unequal distribution of power, not any intrinsic quality of actors, to test the operative import of the concept of "moving localities" and explore the interconnections between Correia da Serra's reflections on the earth sciences $^{2}$ and on history.

Correia da Serra's life was marked by constant itinerancy and extended periods abroad. Born in 1751, he lived in Italy with his family from 1757 to 1777 , and as a young man returned to Portugal where he stayed until 1795, to head the newly founded Academy of Sciences of Lisbon. Due to religious and mostly political problems that will travel with him during all his life, Correia da Serra subsequently fled to London, where he lived

2 The expression "earth sciences" is used here instead of geology or mineralogy because, although anachronistic, its use has the intent of conveying the variety of approaches and fields, ranging from mineralogy, mining, physical geography and cosmogony, etc. to which natural historians and natural philosophers devoted themselves in the eighteenth century. LAUDAN, 1982; HAMM, 1997. 
from 1795 to 1801, then moved to Paris where he settled in until 1812, and finally sailed to the Unites States of America where he lived until 1821 as a diplomat and ambassador of Portugal; he returned to Portugal to die shortly afterwards. As he learned various foreign languages, Correia da Serra was able to write scientific memoirs in Italian, French and English, published them in reputed journals, corresponded with friends and fellow botanists in all three idioms, and actively participated in discussion fora. In this way he consolidated extended international networks of European naturalists, which later encompassed also American peers.

Correia da Serra's epistemological route reveals a trend from fundamentally descriptive accounts authored while in Portugal, to reflective considerations put forward when in Britain and France, to focus again mostly on acute observation and inventory while travelling in the United States of America. They seem to unfold in reaction to the successive geographical and intellectual contexts he found himself in. Especially in what concerns the earth sciences, considerations stem from the early days of Correia da Serra's career, revealing an integrated vision of Man and Nature as dynamical parts of the same whole, which shapes the world inhabited by humans.

The realization that the history of a country does not begin with the origin of its people, but with its own origin as a natural theatre in which natural and human action takes place - "the history of a nation begins not with the origin of its first populations, but with the history of the origins and emergence of the country itself and its lands"- ${ }^{3}$ was the starting point for a historical research program and reflections, outlined while a young man who charted the research agenda of the Academy of Sciences. Subsequently, he reflected on the history of Portugal, when away from his native country but still in Europe, and assessed the state of the old continent upon arriving in the United States.

The entanglement between the earth sciences and history became a constitutive element in Correia da Serra's worldview revealing a

3 ANTT, Manuscritos de Correia da Serra, A30, f.3, dated from 1784. Transcribed in SIMÕES; CARNEIRO; DIOGO, 2003, p.71-79. 
concomitant process of historicization of nature and naturalization of history, occurring at a period in which both the sciences and history were in search for their disciplinary, conceptual and methodological identities: at the epistemological level it asserted the belief in the continuity between the realms of history and the earth sciences, and the similarity between their methodologies, including the objectivity of scientists and historians, the belief in causal relationships, the importance and necessity of proof and the verifiability of laws; at the formal level, historical considerations fostered a discursive association with the scientific realm, through the extensive use of scientific analogies and metaphors and their exploration as rhetorical devices.

\section{FIELD STUDIES AND METHODOLOGICAL Reflections on the EARTh Sciences and History. Views From Portugal}

While still in Italy, the young Correia da Serra exercised his observational skills in a major field trip to the west coast along Liguria with the physician Jean Demeste (1744-1783), which took place in 1774, and the same happened while travelling to Portugal three years later, in $1777,{ }^{4}$ to participate in the Academy of Sciences of Lisbon. ${ }^{5}$

Correia da Serra took upon himself the task of outlining a utilitarian agenda for the academy, sure that the modernization of the country depended on a complete knowledge and survey of its natural resources, and their efficient use through science and technology. This agenda included a renewed scientific and historical assessment of the country, critical to an extended understanding of its economic potentialities. This

4 ANTT, Manuscritos de Correia da Serra, A15. Journal d'une course en Avril 1774. Avec Mr. Demeste. ANTT, Manuscritos de Correia da Serra, A19. Observations d'Histoire Naturelle dans le Patrimoine de S. Pierre en 1776, avec Mr. L’Abbé Chaupuy. ANTT, Manuscritos de Correia da Serra, A21. Observations faites en paurcourant l'Espagne et le Portugal, no 1 . Voyage de Cadiz a Serpa 1777.

5 Correia da Serra was invited by the Duke of Lafões to found the Academy of Sciences in 1779, together with the estrangeirados Domingos Vandelli and Teodoro de Almeida 
much is asserted in the first dated unpublished memoirs, from 1784 and 1785 , which include multiple observations and reflections on the physical structure and mineral composition of Alentejo, the province in which he was born, and which he chose for his field trips in Portugal. ${ }^{6}$ Although it is unlikely that Correia da Serra was influenced by Leibniz's Protogaea (Hamm, 1997), ${ }^{7}$ like other eighteenth-century naturalists, whether or not influenced by the German philosopher, he adopted a practical approach regarding the importance of surveying mineral resources in the context of the "sciences des richesses" characterizing the eighteenth-century episteme (Foucault, 1966), and describing accurately their spatial distribution given their potential economic relevance; but he never focused on mines to draw conclusions about the transformations of the earth or the subterranean structure of the planet.

As a consequence of his move from Italy to Portugal, the confluence of old and new interests arising in different locations converged into the same moving locality: "the same old natural history, a passion long rooted in me, was forced to adapt, so to speak, to this new passion that attracted me to the history of Portugal and to serve as a steward of its study". Because in Correia da Serra's recent view "the history of the motherland did not start with the origin of the people who lived there, but rather with its own origin and birth", it became crucial to "find out which series of successful operations and evolutions nature used to shape Portugal", in order to delineate an integrated view of both its history and natural history through the exploration of similar methodologies.

6 ANTT, Manuscritos de Correia da Serra, A30. Observações sobre a formação e estructura Fisica das tres Provincias Meridionais do nosso Reino. Assembleia de 13 maio 1784 and ANTT, Manuscritos de Correia da Serra, A31. Observações feitas em huma jornada pela provincia do Alentejo em Mayo e Junho de 1785. Both respectively transcribed in SIMÕES; CARNEIRO; DIOGO, 2003, p.71-79, p.81-88.

7 Correia da Serra only refers to Leibniz's Theodicy and to the controversy with Clarke. These references only appear in his youth manuscripts. ANTT, Manuscritos de Correia da Serra, A1-A5. Zibaldone di Materie diverse, No III, Giuseppe Correa. 14 ago. 1767.

8 ANTT, Manuscritos de Correia da Serra, A30. Transcribed in SIMÕES; CARNEIRO; DIOGO, 2003, p.71. 
Figure 1 - Places visited by Correia da Serra in Alentejo, Mapbox/Open Street Maps. ${ }^{9}$

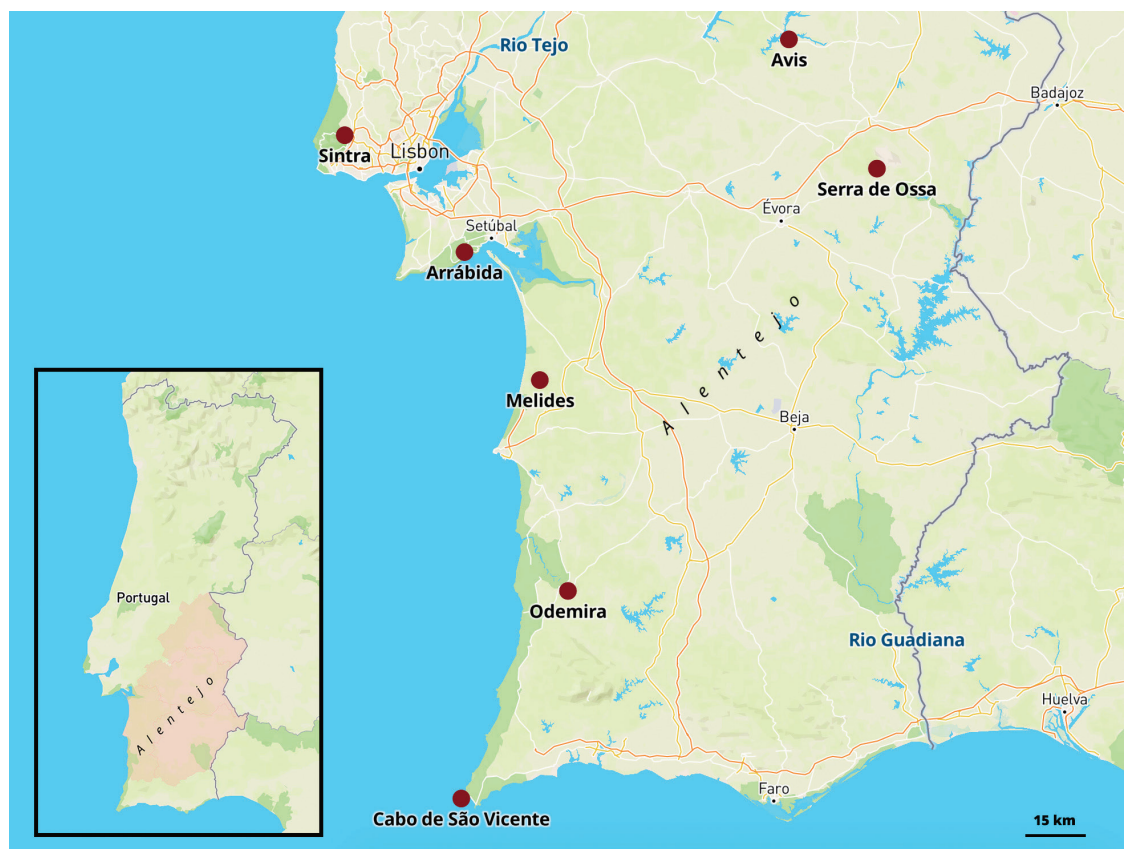

The careful and detailed "geognostic" description of the physical scene of Alentejo, of its hills, valleys and rivers and of the mineral composition of the soil and fossils found in it are the main topic of one of the memoirs, which he considered as the necessary prelude to interpretative hints not prey to unfounded imagination and audacity:

I will not use for this purpose any of the many hypotheses that in the last century so many men have imagined in such a way that in defending them they have given greater proof of the audacity of human knowledge than of the true merit of their proposals; I will introduce you to the phenomena and their immediate consequences, i.e., what there is for real. ${ }^{10}$

9 Mapa elaborado por João Machado a pedido das autoras.

10 ANTT, Manuscritos de Correia da Serra, A30. Transcribed in SIMÕES; CARNEIRO; DIOGO, 2003, p.72. 
Correia da Serra began by describing the orientation of hills and valleys, and of the rivers which cross them, drawing particular attention to the hills between Odemira and Melides, whose north-south orientation is contrary to "the natural laws of nature". ${ }^{11}$ Next, he focused on the mineral composition of the lands and pointed out regional differences: between Beja and Évora one finds granite and rock crystals; to the northeast of Évora all the way to Portalegre, and from the Guadiana to the Cape of St. Vincent, there is clayey shale; north of the Tagus, one finds limestone, with the exception of Lisbon where the soil is of volcanic nature, and Sintra, "a problem for naturalists", ${ }^{12}$ where there is granite on top of limestone; in Arrábida one finds limestone; and the OdemiraMelides range, not yet analyzed, is reserved for future description.

As many fellow naturalists, Correia da Serra was aware of recent proposals concerning materialistic theories of the earth and earth phenomena which defied explanations about the creation of the universe based on Genesis, notably by Georges Louis Leclerc, Count of Buffon (1707-1788), who was primarily a literary naturalist. ${ }^{13}$ Buffon's contributions were taken increasingly as evidence for reconstructing a history of the earth, which no grand theory could predict, given its contingent character. This approach, in addition, coincided with the contemporary growing use by antiquarians and historians of archives and monuments in building up a new kind of historicism, which replaced the earlier "conjectural history" based on deduction, and which was followed by the positivist emphasis on the objectivity of the observer. Like with the human world, the diversity of the natural world was historicized, and

11 ANTT, Manuscritos de Correia da Serra, A30. Transcribed in SIMÕES; CARNEIRO; DIOGO, 2003, p.73.

12 ANTT, Manuscritos de Correia da Serra, A30, f 9v. Transcribed in SIMÕES; CARNEIRO; DIOGO, 2003, p.77.

13 Buffon formulated the basis of a geologic system that deeply marked the eighteenth century and culminated in his work Les Epoques de la Nature (1778). Aiming at advancing a Newtonian cosmogony while avoiding censorship of a theological nature, Buffon divided the history of the Earth into six periods or 'epochs' which could easily correspond to six of the seven days of creation, since on the seventh day the Creator rested. OLDROYD, 1996, p.90-92; HAMM, 1997, p.84; TAYLOR, 1990; 1998; 2001, p.88. 
the static "natural history" of the earth gave way to a temporal history (Rudwick, 1996, p.280-281; Oldroyd, 1979, p.192-213, p.227-257). We argue that this trend announced an increasing historicization of nature, which can be identified in Correia da Serra's (subsequent) incursions in the earth sciences, thereby corroborating Rudwick's claim that the historical element in "natural history" was present even before geognosy was transformed by the use of the fossil criterion (Rudwick, 1996, p.280-281).

In effect, Buffon had formulated the basis of a geologic system that deeply marked the eighteenth century and culminated in his work Les Epoques de la Nature (The stages of Nature) (1778). With the aim of advancing a Newtonian cosmogony while avoiding censorship of theological nature, Buffon divided the history of the earth into six periods, which could easily correspond to six of the seven days of creation (Oldroyd, 1996, p.90-92). According to Buffon's theory, the earth first formed from the Sun, a very hot star which underwent a cooling process that defined various stages of its development. The initial era was a stage of earth fusion followed by a cooling period that allowed the crust to solidify. Regarding the cooling of the earth, Buffon put forward the idea according to which underground heat was the major agent of geological change, a view which linked him to the school of thought currently known as Plutonism or Volcanism, but he never explored further this aspect of his theory. ${ }^{14}$ He opted instead for the theory of receding oceans, thus launching the basis of the theory usually known as Neptunism that Abraham Gottlob Werner (1749-1817), a mineralogist and professor at the prestigious Mining Academy in Freiberg, would eventually develop.

According to Werner's theory, a vast primitive ocean deposited sediments, and later evaporated, leading to the exposure of portions of the earth in a process that, by definition, assumed that the agents of geologic change of the past differ from those active presently (Bowler,

14 He believed that volcanoes were formed by the combustion of coal deposits, and not by the residual heat that resulted from the fusion of the earth. He did not speculate on the intensity of past phenomena or, whether the internal heat had produced earthquakes more violent than the contemporary ones, a theory that was eventually supported by catastrophists such as Georges Cuvier. BOWLER, 1989, p.39-49. 
1989, p.39-49; Laudan, 1987, p.87-112). Although plutonists accepted the formation of sedimentary rocks through sub-aquatic deposition, they rejected the idea that all materials from these rocks had once been suspended in the primitive ocean. In their view, the deposition of sediments on the bottom of the sea resulted from the erosion of pre-existing earth surfaces, which were later exposed due to the rising of the sea floor caused by subterranean pressure and heat (Oldroyd, 1996, p.113-137).

Although referring often to Buffon, Correia da Serra, however, did not hesitate to contradict aspects of his theory, when based on the observations amassed. In fact, he questioned the interpretations of Buffon and of Carl von Linnaeus (1707-1778) on the origin of limestone based on the lack of physical evidence on which to ground their scientific hypotheses:

The common opinion of naturalists, including Linnaeus and Buffon, is that all limestone is derived from animal substances; the fact that two such great men with such opposing views share the same opinion carries much weight; but as natural history does not accept but physical evidence, and I do not want to accept hypotheses, I do not assume animal vestiges where I do not see them. ${ }^{15}$

Regarding the origin of granite, Correia da Serra questioned its sedimentary nature:

Granite is not formed by the deposition of water, it is a self-cohesive solid mass; granite makes up all the lofty mountain ranges of our globe, and all observations show that it is the base that supports on itself all other substances that cover the surface of the earth; it is the oldest of all materials, and consequently the highlands and plains of Beja and Évora and the granite region of the Alentejo province are the oldest of all we have observed. ${ }^{16}$

15 ANTT, Manuscritos de Correia da Serra, A30, f7. Transcribed in SIMÕES; CARNEIRO; DIOGO, 2003, p.76.

16 ANTT, Manuscritos de Correia da Serra, A30, f11-11v. Transcribed in SIMÕES; CARNEIRO; DIOGO, 2003, p.78. 
In other instances, Correia da Serra's considerations seem to indicate a catastrophist perspective, ${ }^{17}$ namely when referring to "the old successes and revolutions of nature", ${ }^{18}$ and the "great movements of the globe". ${ }^{19}$ In general, one may say that the sources of his ideas can be traced back to Buffon, and Johann-Jacob Ferber (1743-1790), a friend of Correia's, who carried out mineralogical studies in Italy. ${ }^{20}$ Correia da Serra quoted both, showing his familiarity with their respective work, as well as his own distance from the biblical narrative. ${ }^{21}$

In 1785, Correia da Serra complemented his previous study on the geological characterization of Alentejo with another one (although incomplete), this time taking a purely historical perspective, aimed at "the knowledge of the mother country".22 Evidence was based on documents found in the castle and registry of Aviz, and in the registries of Serra de Ossa and Cartuxa de Évora. Clearly, natural and historical evidence played complementary roles in the construction of Correia da Serra's worldview.

17 Catastrophism is a theory that advocates that in the past the Earth underwent violent and sudden natural catastrophes like quakes, floods, and quick formation of mountain chains, with worldwide impact, according to some authors. These natural catastrophes are not comparable in magnitude with present time geological phenomena.

18 ANTT, Manuscritos de Correia da Serra, A30, f.2 v. Transcribed in SIMÕES; CARNEIRO; DIOGO, 2003, p.79.

19 ANTT, Manuscritos de Correia da Serra, A30, f12v. Transcribed in SIMÕES; CARNEIRO; DIOGO, 2003, p.79.

20 In his twenties, Correia da Serra became friendly with the Swedish naturalist Johann-Jacob Ferber, a student of Linnaeus, who chose to study the subterranean mineral world. During his mineralogical Grand Tour he travelled in Europe between 1768 and 1773, and in Rome he became acquainted and botanized with Correia da Serra. In 1770, he was appointed to the Royal Department of Mines, and in 1774, professor of physics and natural history at Courland.

21 Hutton only formulated the general principles of Plutonism in 1778, and later in 1795, he organized them in the book Theory of the Earth; Cuvier's catastrophism, in turn, was first explained in 1813, in his essay Essai sur la theórie de la Terre.

22 ANTT, Manuscritos de Correia da Serra, A31, f.1. Transcribed in SIMÕES; CARNEIRO; DIOGO, 2003, p.81. 
The first collection in the registry of Aviz, "one of the most prestigious archives of our history", ${ }^{23}$ held documentation dating from 1134 to the period of the Philippine occupation during the $16^{\text {th }}$ century, covering civil, religious, and military matters. From this vast collection, Correia da Serra singled out two documents: the election of Fernão Rodrigues (Roiz) de Siqueira as successor of João I (by then already King João I (reign 1385-1433) as Master of Aviz, and the first statutes of the Order of Aviz, ${ }^{24}$ dating from the reign of King Henriques (reign 1139-1185), the first king of Portugal. Correia da Serra briefly, but incisively, commented on both manuscripts, criticized the dubious relationship between secular and religious powers, and voiced anti-clerical opinions despite his religious education and being a clergyman. He attacked the Papacy, notably the collection of charters, in which papal material aspirations over Portugal were presented as "causing nausea". ${ }^{25}$

Correia da Serra considered the archives of Serra Ossa and Cartuxa de Évora less valuable from an historical perspective suggesting that they were more interesting concerning Portuguese language. Additionally, comments were made about the history of monuments, namely the castle and the convent of Aviz, and a dolmen near the village Aldeia de Pomares, in the outskirts of Serra de Ossa. Correia da Serra's reflections about the etymology of the word Ossa (whose origin is urso, bear) became a pretext for considerations about the natural history of bears, invoking Buffon's studies about the geographic distribution of these animals in Europe, and their extinction due to human action, and again showing that in his worldview history was intertwined with natural history.

These two documents illustrate that Correia da Serra's interest in historical analyses arouse as a complement to his work as a naturalist,

23 ANTT, Manuscritos de Correia da Serra, A31, f.2. Transcribed in SIMÕES; CARNEIRO; DIOGO, 2003, p.82.

24 Previously Master of Aviz, King João I was elected following a civil war.

25 ANTT, Manuscritos de Correia da Serra, A31, f.6. Transcribed in SIMÕES; CARNEIRO; DIOGO, 2003, p.87. 
and that for him both shared the same kind of methodological objectivity. Contrary to the genre he used in the travelogue of his journeys with Demeste along Liguria, ten years earlier, Correia da Serra now emphasized that he did not choose "the method of the travelogue, apparently more natural because the history of the observer is seldom necessary to assess the observation. In general, it is of no use to know how many steps the observer took, the goal is to know the ideas he reached through them". ${ }^{26}$ In these statements, the importance conceded to the objectivity of the observer point that from the epistemological point of view Correia da Serra shared what came to be the positivism of Auguste Comte (1798-1857), in the $19^{\text {th }}$ century: the belief of Leopold von Ranke (1795-1886) in the recovery of the historical past "as it really occurred" ("wie es eigentlich gewesen") became paradigmatic of this historical trend, which besides the objectivity of the observer, ascertained also the belief in cause-effect relationships, the importance and necessity of proofs and the verifiability of laws. This trend culminated in the ideas of Benedetto Croce (1860-1952) on the nature of historical knowledge and its similarities with knowledge in botany, zoology and geology (Collingwood, 1946; Gardiner, 1952; Gould, 1987).

All these were aspects already emerging in Correia da Serra's initial unpublished texts, which were subsequently put to work in the historical program implemented when he became secretary of the Academy in 1788, replacing the Count of Barbacena, who was then appointed as governor of Minas Gerais (Brazil).

In his new capacity, the Abbé began by preparing the História $d a$ Academia Real das Ciências de Lisboa desde o seu estabelecimento em 1780 até 1788 (The History of the Royal Academy of Sciences of Lisbon from Its founding in 1780 till 1788), before enrolling in a grand project of a History of Portugal. He emphasized his vision of continuity and increasing perfection of historical events and their relationship with scientific progress, by reviewing the enlightened program of reforms of

26 ANTT, Manuscritos de Correia da Serra A31, f.1. Transcribed in SIMÕES; CARNEIRO; DIOGO, 2003, p.81. 
King José I (reign 1750-1777) at the University of Coimbra, followed by his daughter Queen Maria I (reign 1777-1799):

Troubled days followed until King José allowed light to once again shine with the happy reform of the University of Coimbra, and put Portuguese people back to the path to true knowledge. The old sciences are again taught with principles and methodology, and he introduced among us the study of other sciences. Since this memorable time our people started to turn their eyes to the study of nature and the exact sciences, and each year has seen a gradual increase in the number of those who love and foster them; and at the same time there is a growing curiosity and attention among the public toward their study on which much of its happiness depends.

Shortly before the reform of the University, the changes that took place in public education had produced a similar effect in the study of humanities. The critical nature and the propensity for the old original classics had insensibly moved from the Latin schools of literature to the study of national ones. The fathers of our history and the good authors who shaped our language in the sixteenth century were not only read again, but studied; and along with them, sobriety, good taste, and a more serious critical analysis again claimed their place in Portuguese literature. ${ }^{27}$

Once again, for Correia da Serra the modernization of the country and its progress were tied to the joint development of the new sciences and an innovative approach to its history, both informed by the same methodological options. Therefore, it is no wonder that he outlined various projects oriented towards the promotion of science, literature, and history. He particularly cherished the writing of a History of Portugal that would include themes such as economy, politics, social structure and culture, as well as a dictionary of Portuguese language and the publication of previously unpublished sources of Portuguese history.

27 ANTT, Manuscritos de Correia da Serra, A58. 
The elaboration of a History of Portugal was based on a systematic survey, inventory, transcription, and publication of previously unpublished documents. Amidst Correia da Serra's documents related to this project, currently kept in the archives of Torre do Tombo, there is one that lists two hundred and fifty seven previously unpublished documents about the history of Portugal; additionally, there is a draft of the first chapter of the History of Portugal, ${ }^{28}$ a monumental project that never made it past the first few pages; ${ }^{29}$ there are also some memoirs of related themes that range from art, jurisprudence, and commercial relations with foreign nations to the history of the first peoples and the first centuries of the Portuguese monarchy. ${ }^{30}$ The survey was carried out by academicians especially trained for this purpose by Correia da Serra, who were granted royal permission to examine national and Spanish registries, traveled in Portugal and regions of Spain carrying out historical fieldwork between 1788 and $1794 .^{31}$

Influenced by Condorcet (1743-1794), Correia da Serra considered the publication of previously unpublished documents a fundamental task in the reconstruction of history otherwise irreparably lost. ${ }^{32}$ For him, history was a continuous and interconnected movement in which the present is understood in function of the past, and holds the seeds to "predicting" the future: "the laws that govern us, the classes of people into which the nation is divided, the forums, privileges, and obligations of each one of us, the nature of the property we own, our ways of public administration, the customs we follow, the language we speak,

28 ANTT, Manuscritos de Correia da Serra, A65.

29 ANTT, Manuscritos de Correia da Serra, A33-A.

30 ANTT, Manuscritos de Correia da Serra, A25, A28, A29, A35, and A36.

31 This group included João Pedro Ribeiro, a Law Professor at the University of Coimbra, who covered the north and center of Portugal, Father Joaquim de Santo Agostinho who traveled across the Algarve, and Joaquim José Ferreira Gordo who traveled to Spain, where he obtained permission from the Count of Floridablanca to visit the Royal Library in Madrid, and the archives of Escurial and Simancas.

32 ANTT, Manuscritos de Correia da Serra, C7. 
all are consequences of past successes". ${ }^{33}$ Materializing the entanglement of science and history in Correia da Serra's worldview - "the exact knowledge of our country, if it is not the most sublime of all, it is certainly the one that matters the most" $-{ }^{34}$ he presented eight reflections before the Academy, four on utilitarian science and the remaining on history, addressing the basis of nations, namely in judicial and historical terms. None of these, however, were published. ${ }^{35}$ The Memória sobre os primeiros povoadores de Portugal (Memoirs on the first settlers of Portugal) and the Observações sobre os monumentos (Observations on Monuments) ${ }^{36}$ raise recurrent issues in the Abbés work on history, namely the relationships between past, present, and future, and the importance of interpreting historical memories in contextual terms, in the light of their own time and "considered in themselves independently". ${ }^{7}$

Summing up, on a methodological level, the transposition of a scientific approach to the field of history, characteristic of the Enlightenment, justified the use of such concepts as utility, objectivity of the observer, verifiability of laws, causal relationships, and the emphasis on proof. ${ }^{38}$ All were grounded on systematic and careful inventory of primary sources: "monuments and the narrations of contemporaries" constitute the only witnesses not affected by interpretations, and are "the sole basis of the certainty of history" (Correia da Serra, 1790, p.VII), testifying to Correia da Serra's adherence to the emerging style of historicism.

33 CORREIA DA SERRA, José Francisco. Discurso Preliminar. Colecção de Livros Inéditos de História Portuguesa dos Reinados de D.João I, D. Duarte, D. Afonso V e D. João II. Lisboa, 1790, p.VII-XI, p.VII.

34 ANTT, Manuscritos de correia da Serra, A30 and A31. Transcribed in SIMÕES; CARNEIRO; DIOGO, 2003, p.71-79, p.81.

35 ANTT, Manuscritos de Correia da Serra, A23.

36 ANTT, Manuscritos de Correia da Serra, A25 and A35.

37 ANTT, Manuscritos de Correia da Serra, A35, f1.

38 Correia da Serra claimed that "without certainty, however, all study is in vain" (1790, p.VII). In ANTT, Manuscritos de Correia da Serra, A35, f.3, he claimed that the observer should "refrain from advancing ideas without authority and examination, combining the order of time and place, clarifying sources, assessing the weight of signs and analogies and considering the nature of things". 
Additionally, as for him geognostic features and physical geography conditioned human history, one can argue that history became in this way naturalized.

\section{FIELD STUDIES AND METHODOLOGICAL REFLECTIONS ON THE EARTH SCIENCES AND History. VieWS From EURope AND THE United STATES OF America}

In 1795, Correia da Serra felt forced to abandon Portugal for political reasons, travelling first to Britain where he occupied a diplomatic position at the Portuguese Legation in London, and subsequently fleeing to Paris as he became a persona non grata to the Portuguese ambassador. This European period was undoubtedly the most fruitful of Correia da Serra's scientific life, and the one to which were associated his most original contributions to botany.

As he was becoming a dynamic player and spirited communicator in an international network of naturalists, he continued to strive in order to reshape the Portuguese scientific landscape, namely through letters to his allies, counselling, and shipment of specimens and various materials. He was both away from his country and within it, to such an extent that if there was an element of contingency spurred by his travelling experiences, reacting to encounters and the immediate contexts he was going through, especially in what relates to scientific original reflections, there is also an element of continuity in his thought and actions prompted by his will to renovate the Portuguese cultural landscape. The same happened when leaving Europe for the United States of America.

While in Britain where Correia da Serra became under the protection of Banks, they both went on a field trip to Sutton, located on the Lincolnshire coast, in England, to study the moorland islets primarily made up of decomposed trees that stretch along the coast, but only visible during the lower annual tides, and extending for some sixty miles south of Sutton.

The observations dated from 1796, when Correia da Serra had just become a member of the Royal Society, and were published in the 
Philosophical Transactions of the Royal Society under the title "On a submarine forest on the east coast of England".

In a sequence similar to the one used in the Alentejo manuscripts, in the first part of the paper facts are described, and in the second hypotheses are put forward, paying heed to Correia da Serra's belief that: "in geology, more perhaps than in any other branch of natural science there is a necessity of strictly separating the facts observed form the ideas which, to explain them, may occur to the mind of the observer". ${ }^{9}$

The islets were primarily made up of roots, branches, and leaves from trees and shrubs, mixed with leaves from aquatic plants. Some of the remains of trees were still set on roots and there were trunks scattered on the ground in all directions due to their economic potential: "the people of the country have often found among them very sound pieces of timber, fit to be employed for several economical (sic) purposes". ${ }^{4}$ Correia da Serra proceeded to identify some trees as birch, fir, and oak, and described the soil where these trees were found as soft and fatty clay with underground levels of decayed leaves, some of which he could also identify.

Correia da Serra proceeded to find out answers to questions such as: "what is the epoch of this destruction?" and "by what agency was it effected?". ${ }^{41}$ He believed that some of the samples of fossilized plants found might have developed in two distinct stages of earth's history, and therefore had different origins. The remains and traces of plants found in shale or limestone's mountains resulted from plants now found in the tropics. These plants could not have grown in these latitudes, nor could they have been transported or deposited there by any of the forces currently active in nature. ${ }^{42}$ The nature and arrangement of the materials

39 CORREIA DA SERRA, José Francisco. On a submarine Forest, on the East Coast of England. Philosophical Transactions of the Royal Society of London, 1799, p.145-156, p.145. Transcribed in SIMÕES; CARNEIRO; DIOGO, 2003, p.89-96.

40 CORREIA DA SERRA, 1799, p.146. Transcribed in SIMÕES; CARNEIRO; DIOGO, 2003, p.90.

41 CORREIA DA SERRA, 1799, p.150. Transcribed in SIMÕES; CARNEIRO; DIOGO, 2003, p.92.

42 CORREIA DA SERRA, 1799, p.150. Transcribed in SIMÕES; CARNEIRO; DIOGO, 2003, p.92. 
that make up these deposits could not be explained by "any of the acting forces under the present constitution of nature" ${ }^{43}$ Here as in the former manuscripts, Correia da Serra clearly aligned himself with catastrophism, and concluded that in order to explain such occurrences we would have to go back in time to the period in the planet's history when the sea level was far higher than its current level, covering the top of the secondary mountains where these traces of tropical plants were found. ${ }^{44}$

As to Sutton's submersed forests Correia da Serra believed that they were accounted for by a second set of events, the remains found in the clay or in layers of sand resulting from "the slow depositions of the sea or the rivers, agents still at work under the present constitution of our planet" ${ }^{45}$ For him, these fossils were found in flat lands of recent formation. Before reaching a definite conclusion about the origin of these submersed forests, Correia da Serra analyzed alternative theories, which he dismissed promptly, to come to the conclusion that the "forest here described grew in a level high enough to permit its vegetation; and that the force (whatever it was) that destroyed it, lowered the level of the ground where it stood" ${ }^{46}$ The force in action in this case must have been a "force of subsidence," which since it is a natural consequence of gravity and more effective in soft grounds, could have had "its action sometimes quickened and rendered sudden by extraneous causes, for instance, by earthquakes". ${ }^{47}$ In his perspective this explanation was simple, its probability confirmed by many similar situations, and not subject to such objections as those voiced against the theory of "alternate depression and elevation of the level of the ocean", 48 an opinion that to

43 CORREIA DA SERRA, 1799, p.150. Transcribed in SIMÕES; CARNEIRO; DIOGO, 2003, p.92. 44 CORREIA DA SERRA, 1799, p.150. Transcribed in SIMÕES; CARNEIRO; DIOGO, 2003, p.92-93.

45 CORREIA DA SERRA, 1799, p.151. Transcribed in SIMÕES; CARNEIRO; DIOGO, 2003, p.93. 46 CORREIA DA SERRA, 1799, p.152-153. Transcribed in SIMÕES; CARNEIRO; DIOGO, 2003, p.94.

47 CORREIA DA SERRA, 1799, p.153. Transcribed in SIMÕES; CARNEIRO; DIOGO, 2003, p.94. 48 CORREIA DA SERRA, 1799, p.154. Transcribed in SIMÕES; CARNEIRO; DIOGO, 2003, p.95. 
be credited required in his view more proof than that available, even if defended by a "genius" like Lavoisier. ${ }^{49}$

In this article, Correia reiterated the views he expressed in his observations in Alentejo, Portugal, over a decade earlier. His interpretation continues to be in line with catastrophism since he recognized that the Earth had gone through various stages during which the agents of geological change acted with different degrees of intensity not at work presently.

Later in his life, while already in the United States of America where among other leading figures of the young nation, he became very close to Jefferson, a freemason like himself, Correia da Serra enrolled in various field trips covering many states of the young nation, to such an extent that he became an expert on the American territory. As when back in Portugal, the survey of natural resources was given priority as a preliminary to their successful exploitation. It was in this context that he returned to the earth sciences. His reflections gave way to the article "Observations and Conjectures on the Formation and Nature of the Soil of Kentucky", read before the American Philosophical Society in 1815, and published three years later in its Transactions. ${ }^{50}$ Correia da Serra revisited questions raised in the article mentioned above, and once again endorsed catastrophism, despite making no reference to Cuvier, whom he had met regularly at the Jardin des Plantes, in Paris, immediately prior to his journey to the United States.

Correia da Serra followed again the same methodological approach outlined in former manuscripts and publications on the earth sciences: description of the nature and formation of Kentucky soil preceded hypotheses to explain the causes of its unusual fertility. In his view, when compared with the neighboring regions, the "Elkhorn tract" dated from a period in Earth history that followed the great geological revolutions, a fact he considered quite obvious due, on the one hand, to the horizontal

49 CORREIA DA SERRA, 1799, p.154. Transcribed in SIMÕES; CARNEIRO; DIOGO, 2003, p.95.

50 CORREIA DA SERRA, José Francisco. Observations and Conjectures on the Formation and Nature of the Soil of Kentucky. Philosophical Transactions of the American Philosophical Society, vol. 1, p.174-180, 1818. Transcribed in SIMÕES; CARNEIRO; DIOGO, 2003, p.97-101. 
orientation of ground layers (as opposed to the older regions), with fractured rocks "worked and shaped by one or more posterior revolutions" 51 and, on the other, to the existence of remains of aquatic plants and animals that once inhabited the region when it was still submersed by the sea.

The fertility of this region, due primarily to the great amount of plants deposited, reached its highest point in the elevated ground areas, and decreased as it went down in the direction of water courses. The issue of plant deposits and the conditions of their decomposition held, in Correia da Serra's opinion, the key to understanding the "Elkhorn tract".

Travelling experiences were also behind the re-articulation of Correia da Serra's integrated science-history worldview. While his various original contributions to botany were fostered by questions at the international forefront of research, his few contributions to the earth sciences, as we saw above, were a direct consequence of circumscribed field trips, and gave way to publications in reputed journals, contrary to the unpublished memoirs written during the Academy's period. Interestingly, in what relates to historical matters, the creation of possibilities for a new practice of history behind the Portuguese Academy's project gave way to considerations on the history of Portugal and Europe, written when he was already away, first in Paris, but still in Europe, and then far away from the Old Continent in the United States of America, as if travelling allowed him to gain the necessary geographical and intellectual distance for an objective historical reflection. They provide exemplary illustrations of the operative import of the concept of moving localities.

Concerning Correia da Serra's published historical work, perhaps the most relevant is the extensive and significant article he contributed to the Archives Littéraires de l'Europe entitled "De l'état des sciences et des lettres parmis les Portugais pendant la seconde moitié du siècle dernier" ("Of the state of science and literature among the Portuguese during the second half of the last century"). It was written following his British stay,

51 CORREIA DA SERRA, 1818, p.174. Transcribed in SIMÕES; CARNEIRO; DIOGO, 2003, p.97. 
while already in France, where to make ends meet he also contributed several short entries to Biographie Universelle, Ancienne et Moderne.

Despite having been the victim of political persecutions that affected his scientific career, Correia da Serra systematized, in historical terms, his perspective on the evolution of cultural and political life in Portugal, never commenting on the pressures exercised by political powers on him and others, and therefore putting into practice his adoption of the methodological rules underlying historicism.

Likewise, he strove to present an objective narrative, although not free from value judgments, which divided Portuguese intellectual history, encompassing both science and literature, into three periods. The first corresponded to the period of the maritime discoveries of the $15^{\text {th }}$ and $16^{\text {th }}$ centuries, when the country "showed knowledge and good taste" at the level of the most enlightened nations. ${ }^{52}$ The second, encompassing 229 years, started during the reign of King João II (reign 1481-1495), in 1521, and stretched all the way to the reign of King João V (reign 1707-1750), in 1750; this period was marked by a general state of ignorance and unequalled subservience, dominated by the idea that "opposition to novelty was necessary to keep public morals and order" (Correia da Serra, 1804, p.64). Finally, the third period started during the reign of King José I and was characterized by the rediscovery of science and literature, made possible through Pombal's many reforms, which "returned to the Portuguese good taste and interest in the sciences" (Correia da Serra, 1804, p.65). He had already made similar comments in manuscript form in preparation for writing the history of the first years of the Academy of Sciences. Correia da Serra subscribed to his educational and cultural options, both at the epistemological and organizational levels, and particularly praised, once again, the reform of the University of Coimbra as a materialization of the Enlightenment spirit:

52 CORREIA DA SERRA, José Francisco. De létat des sciences et des lettres parmi les Portugais pendant la seconde moitié du siècle dernier. Archives Littéraires de L'Europe, vol. 1, p.63-77, p.269-290, 1804, p.63. 
There was a total change of staff and rationale. Physical sciences and mathematics were given a prominent role. At great financial effort, foreign experts were invited to teach. We witnessed, as if by magic, the appearance of an astronomy observatory, a chemistry laboratory, a botanical garden, an anatomical theater, and a natural history cabinet, all richly equipped with instruments and objects, all in a city where, up until then, sciences and institutions for their teaching were ignored. Theology, law, medicine, and fine arts were equally established according to truly European standards. (Correia da Serra, 1804, p.72).

The spirit of modernity of the reign of King José I carried over to the reign of his daughter Queen Maria I who sponsored the creation of new scientific institutions such as the Academy of Sciences of Lisbon, "a permanent society with the goals of promoting the advancement of the sciences and perfecting taste in Portugal" (Correia da Serra, 1804, p.270), which impacted on the Portuguese scientific and intellectual landscape through its sessions, the publication of Memoirs authored by important members of the Portuguese intellectual elite, and through research projects, not always successful, aimed at pushing forward its utilitarian agenda.

While a diplomat in the United States of America, what Jefferson expected to be a calm job for Correia da Serra, leaving ample time for botanizing and scientific discussions turned out to be a difficult period due to anti-colonial and anti-Portuguese movements in South America, supported by some north-Americans. The independence of Brazil was lurking on the horizon, anticipated by various revolts, including the recent one in Pernambuco, whose consequences Correia da Serra tried to minimize by avoiding that the head conspirator be received in the official political circles of the United States.

In the few leisurely moments left from his diplomatic duties, Correia da Serra and Jefferson discussed a project of a new international order opposing the Old Continent, and dividing the American one between the United States, in the north, and Portugal, in the south (Bourdon, 1975; 1993; Cohen, 1995; Faria, 2001), a reborn nation following the transfer of its center of gravity from Europe to Brazil, with the move of 
the king and his court from Lisbon to Rio de Janeiro. ${ }^{53}$ Jefferson's political project included the idea that:

Nothing is so important as that America shall separate herself from the systems of Europe, \& establish one of her own. Our circumstances, our pursuits, our interests are distinct. The principles of our policy should be so also. All entanglements with that quarter of the globe should be avoided if we mean that peace \& justice shall be the polar stars of the American societies. ${ }^{54}$

Correia da Serra's diplomatic practice, together with his historical reflections over Europe's past and future published in the American Review of History and Politics, in 1812, under the title "General considerations upon the past and future state of Europe", allowed him to play an active role in the political project of a new hegemonic American hemisphere. ${ }^{55}$

Again, the reflections on Europe are interspersed by considerations reasserting methodological similarities between the historical and scientific realms, and again they illustrate how the extended travels of Correia da Serra fostered reflections where his past experiences played an integral role. They were convened to inform present problems and future actions, to such an extent that in each location Correia da Serra found himself, the role of moving localities informed the implementation of his agenda. The importance of history as an element of prediction, and consequently as a potential tool for reflecting over political praxis is asserted: "in exploring historical futurity, we are necessarily curtailed

53 The project was cherished by many Portuguese intellectuals, but was opposed by part of the commercial bourgeoisie, which was able to impose its vision following the revolution of 1820 , the return of the royal family to Portugal, and the establishment of a constitutional monarchy.

54 Letter from Jefferson to Correia da Serra, 24 oct. 1820. Transcribed in DAVIS, 1993, p.298-299.

55 A second and rather similar version was published in 1813, and a much abbreviated one was published in 1815. All these articles can be found in FARIA, 2001. CORREIA DA SERRA, José Francisco. Heads of an essay on the future state of Europe. Correspondence respecting Russia, between Robert Goodloe Harper, Esq. and Robert Walsh Jun. Philadelphia: 1813. CORREIA DA SERRA, José Francisco. Considerações gerais sobre o estado passado e futuro da Europa. Observador Lusitano em Pariz, vol. 1, p.497-515, 1815. 
of essential means (...) yet there remain to us data sufficiently broad, upon which to build conjectures not unacceptable to sound reason". ${ }^{56}$ The emphasis was placed, on the one hand, on the concepts of nation and identity (possibly influenced by Hegel's work), and on the other, on the common heritage shared by Europe.

The parallel exploration of connections between the earth sciences and history is particularly evident in this article in which they cover both the methodological and rhetorical levels. In fact, Correia da Serra frequently resorted to scientific analogies and metaphors, associating historical moments to "catastrophes", "erupting volcanoes", or "inflammable materials on fire" (Correia da Serra, 1812, p.355, p.356, p.362, p.366). For an advocate of Plutonism and catastrophism, the above analogies are particularly telling as they associate the same sort of processes to the earth as a body and the body politic, establishing conceptual bridges between the two realms of history and the earth sciences in Correia da Serra's worldview. Like the search for natural laws, Correia da Serra proposed to codify the domain of history, and to underscore the limits imposed by natural order to the development of historical events.

This operation of nature contending against the views of governments, may be remarked at every step in the history of Modern Europe. We everywhere find the nations consolidating themselves in her (sic) frames; dynasties and states, agitated, beating against, and destroying each other like the waves of ocean, but yet finishing, by assuming the forms she had thus destined for them. (Correia da Serra, 1812, p.357).

\section{Conclusion}

The contributions of Correia da Serra to the earth sciences, from the early manuscripts to the published ones, offer a privileged window to grasp methodological commitments and allegiances in the realm of

56 CORREIA DA SERRA, José Francisco. General considerations upon the past and future state of Europe. American Review of History and Politics, vol. 4, p.354-366, 1812, p.355. 
the earth sciences and history, two areas which became entangled in Correia da Serra's thinking and practice since the time he was heading the destiny of the Academy of Sciences.

By probing his initial considerations and contrast them with the changing contexts, which gave way to the later publications on both topics, one corroborates Correia da Serra's systematic concern for objective factual descriptions as the springboard for setting a secure interpretative framework. Simultaneously, one follows his constant allegiance to historicism, as an extension of methods being tested in the earth sciences to history, moulding first a program of survey and inventory of historical sources as a pre-requisite for the writing of a History of Portugal based on novel foundations, and then creating the context for his reflections on Portugal and on Europe. These materialized respectively his perspective both as an estrangeirado who aimed at the modernization of his home country and as a citizen of the world weaving a political agenda for the future hegemony of the American continent in the chessboard of nations.

Having this in mind, we argued that his perspective and approach both to the earth sciences and history are intertwined in building Correia da Serra's worldview, interpreting it as an instantiation of the historicization of nature and the naturalization of history, first explored at the methodological level and subsequently extended to the metaphorical one. The various stages of Correia da Serra's involvement in the making and thinking about history cannot be dissociated from his various travelling experiences, encounters, discussions and reflections ensuing from them, and the creative ways he found to articulate former expectations and agendas to present problems and plans. In our view, they illustrate forcefully how moving localities help reinterpret the multifarious consequences of successive encounters, and reappraise former notions of locality still too tied to a geographical and physical location, signalling a dynamical emergence of a stratigraphy of values, which is continually updated with new interactions, and thus shapes the traveller's choices and actions at each point of the trajectory. Finally, they reinforce the view of circulation as a continuous creative process, and not as punctuated creative moments, to which contribute various 
clusters - scientific, political, ideological - that should be taken seriously into consideration to gain a deep understanding of evolving asymmetrical - and never flat — scientific landscapes.

\section{ACKNOWLEDgMents}

We thank Junia Furtado for the invitation to participate in this issue and the anonymous referees for comments and suggestions. The research for this article was supported by the Project UID/HIS/00286/2013 of the Portuguese Foundation for Science and Technology (FCT) which sponsors the research group Centro Interuniversitário de História das Ciências e Tecnologia (CIUHCT), to which we all belong.

\section{BIBLIOGRAPHICAL REFERENCES}

APPADURAI, Arjun (org.). Globalization. Durham and London: Duke University Press, 2001.

BOURDON, Léon. Afterword. In: DAVIS, Richard Beale. The Abbé Correa in America, 1812-1820: The Contributions of the Diplomat and the Natural Philosopher to the Foundations of our National Life. Providence: Gavea Brown, 1993. p.335-365.

BOURDON, Léon. José Corrêa da Serra, ambassadeur du Royaume-Uni de Portugal et Brésil a Washington, 1816-1820. Paris: Fundação Calouste Gulbenkian/Centro Cultural Português, 1975.

BOWLER, Peter J. Evolution. The History of an Idea. Berkeley: The University of California Press, 1989.

CARNEIRO, Ana; SIMÕES, Ana; DIOGO, Maria Paula. Enlightenment Science in Portugal: the Estrangeirados and their Networks of Communication. Social Studies of Science, vol. 30, p.591-619, 2000.

CARNEIRO, Ana; SIMÕES, Ana; DIOGO, Maria Paula (orgs.). José Francisco Correia da Serra: Investigações Botânicas. Porto: Porto Editora, 2003.

COHEN, I. Bernard. Science and the Founding Fathers. Science in the Political Thought of Thomas Jefferson, Benjamin Franklin, John Adams \& James Madison. New York: W.W. Norton \& Company, 1995. 
COLLINGWOOD, Robin George. The idea of History. Oxford: Oxford University Press, 1994 [1946].

DAVIS, Richard Beale. The Abbé Correa in America, 1812-1820: The Contributions of the Diplomat and the Natural Philosopher to the Foundations of our National Life. Providence: Gavea Brown, 1993.

DIOGO, Maria Paula; CARNEIRO, Ana; SIMÕES, Ana. The Portuguese Naturalist Correia da Serra (1751-1823) and his Impact on Early NineteenthCentury Botany. Journal of the History of Biology, vol. 34, p.353-393, 2001. DIOGO, Maria Paula; GAVROGLU, Kostas; SIMÕES, Ana. FORUM STEP matters. Technology \& Culture, vol. 57, n. 4, p.926-997, 2016.

FARIA, António. Concepção de História e Prática Política. Serpa: Câmara Municipal de Serpa, 2001.

FOUCAULT, Michel. Les mots et les choses - une archéologie des sciences humaines. Paris: Editions Gallimard, 1966.

GARDINER, Patrick. The nature of historical explanation. Oxford: Oxford University Press, 1979 [1952].

GAVROGLU, Kostas. The STEP (Science and Technology in the European Periphery) Initiative: Attempting to Historicize the Notion of European Science. Centaurus, vol. 54, n. 4, p.311-328, 2012.

GAVROGLU, Kostas et al. Science and Technology in the European Periphery. Historiographical Reflections. History of Science, vol. 46, n. 2, p.153-175, 2008.

GOULD, Stephen Jay. Time's arrow, time's cycle. Harvard: Harvard University Press, 1987.

HAMM, Ernie P. Knowledge from Underground: Leibniz Mines the Enlightenment Earth Sciences History, vol. 16, n. 2, p.77- 99, 1997.

LAUDAN, Rachel. From Mineralogy to Geology. The Foundations of a Science, 1650-1830. Chicago: The University of Chicago Press, 1987.

LAUDAN, Rachel. Tensions in the Concept of Geology: Natural History or Natural Philosophy? Earth Sciences History, vol. 1, n. 1, p.07-13, 1982. MACEDO, Jorge Borges de. "Estrangeirados", um conceito a rever. Lisboa: Edições do Templo, 1979. 
MIRANDA, Tiago C. P. dos Reis. "Estrangeirados": A questão do isolacionismo português nos séculos XVII e XVIII. Revista de História, vol. 70, n. 123-124, p.35-70, 1990/1991.

OLDROYD, David. Historicism and the Rise of Historical Geology. History of Science, vol. 17, n. 3, part I, p.192-213; n. 4, part II, p.227-257, 1979. OLDROYD, David. Thinking about the Earth: A History of Ideas in Geology. Cambridge: Harvard University Press, 1996.

PALMA-FERREIRA, João. Academias literárias dos séculos XVII e XVIII. Lisboa: Biblioteca Nacional, 1987.

PATINIOTIS, Manolis. Between the local and the global: History of science in the European periphery meets post-colonial studies. Centaurus, vol. 55, n. 4, p.361-384, 2013.

POLANCO, Xavier (ed.). Naissance et développement de la science-monde. Production et Reproduction des Communautés Scientifiques en Europe et en Amérique Latine. Paris: Éditions de la Decouverte, 1990.

RAJ, Kapil. Beyond Postcolonialism .... and Postpositivism: Circulation and the Global History of Science. Isis, vol. 104, n. 2, p.337-347, 2013.

RAJ, Kapil. Introduction: circulation and locality in early modern science. British Journal for the History of Science, vol. 43, n. 4, p.513-517, 2010. RAJ, Kapil. Relocating Modern Science: Circulation and the Construction of Knowledge in South Asia and Europe 1650-1900. Hampshire: Palgrave Macmillan, 2007.

RAPOSO, Pedro M. P. et al. Moving Localities, and Creative Circulation: Travels as Knowledge Production in $18^{\text {th }}$ century Europe. Centaurus, vol. 56, p.167-188, 2014.

ROBERTS, Lissa. Situating Science in Global History: Local Exchanges and Networks of Circulation. Itinerario, vol. 33, n. 1, p.09-30, 2009.

RUDWICK, Martin J. S. Minerals, Strata and Fossils. In: JARDINE, Nick; SECORD, James; SPARY, E. C. (orgs.). Cultures of Natural History. Cambridge: Cambridge University Press, 1996. p.266-286.

SECORD, James. Knowledge in Transit. Isis, vol. 95, n. 4, p.654-672, 2004. SIMÕES, Ana; CARNEIRO, Ana; DIOGO, Maria Paula. Constructing Knowledge: Eighteenth-century Portugal and the New Sciences. Archimedes, vol. 2, p.01-40, 1999. 
SIMÕES, Ana; CARNEIRO, Ana; DIOGO, Maria Paula (orgs.). José Francisco Correia da Serra: Itinerários Histórico-Naturais. Porto: Porto Editora, 2003.

SIMÕeS, Ana; DIOGO, Maria Paula; CARNEIRO, Ana. Cidadão do Mundo. Uma Biografia Científica do Abade Correia da Serra. Porto: Porto Editora, 2006.

SIMÕES, Ana; DIOGO, Maria Paula; CARNEIRO, Ana. Citizen of the world. A scientific biography of Abbé Correia da Serra. University of California, Berkeley: Institute of Governmental Studies Press, 2012.

SIVASUNDARAM, Sunjit. Focus: Global Histories of Science - Introduction. Isis, vol. 101, n. 1, p.95-97, 2010.

TAYLOR, Kenneth L. American Geological Investigations and the French, 1750-1850. Earth Sciences History, vol. 9, n. 2, p.118-125, 1990.

TAYLOR, Kenneth L. Earth and Heaven, 1750-1800: Enlightenment Ideas about the Relevance to Geology of Extra Terrestrial Operations and Events. Earth Sciences History, vol. 17, n. 2, p.84-91, 1998.

TAYLOR, Kenneth L. The Beginnings of a Geological Naturalist: Desmarest, the Printed Word, and Nature. Earth Sciences History, vol. 20, n. 1, p.4461, 2001. 